Canadian

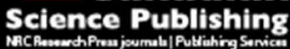

Canadian Journal of Zoology Revue canadienne de zoologie

\title{
Dietary niche partitioning among black bears, grizzly bears and wolves in a multi-prey ecosystem
}

\begin{tabular}{|r|l|}
\hline Journal: & Canadian Journal of Zoology \\
\hline Manuscript ID & cjz-2016-0258.R1 \\
\hline Manuscript Type: & Article \\
\hline Date Submitted by the Author: & 05-Mar-2017 \\
\hline Complete List of Authors: & $\begin{array}{l}\text { Merkle, Jerod; University of Wyoming, Wyoming Cooperative Fish and } \\
\text { Wildlife Research Unit } \\
\text { Polfus, Jean; University of Manitoba } \\
\text { Derbridge, Jonathan; University of Arizona, School of Natural Resources } \\
\text { and the Environment } \\
\text { Heinemeyer, Kimberly; Round River Conservation Studies }\end{array}$ \\
\hline Keyword: & $\begin{array}{l}\text { Ursus americanus, Ursus arctos, Canis lupus, Rangifer tarandus, } \\
\text { PREDATION < Discipline, stable isotope analysis, diet }\end{array}$ \\
\hline
\end{tabular}


1 Dietary niche partitioning among black bears, grizzly bears and wolves in a multi-prey

2 ecosystem

3

4 Jerod A. Merkle $^{\mathrm{a}}$, Jean L. Polfus ${ }^{\mathrm{b}}$, Jonathan J. Derbridge ${ }^{\mathrm{c}}$, and Kimberly S. Heinemeyer ${ }^{\mathrm{d}}$ 5

$6 \quad{ }^{a}$ Wyoming Cooperative Fish and Wildlife Research Unit, Department of Zoology and

7 Physiology, University of Wyoming, Dept. 3166, 1000 East University Avenue, Laramie,

$8 \quad$ Wyoming, USA 82071; jmerkle@uwyo.edu

9 batural Resources Institute, University of Manitoba, 303-70 Dysart Road, Winnipeg, Manitoba,

10 Canada R3T 2M6; jeanpolfus@gmail.com

$11{ }^{\mathrm{c}}$ School of Natural Resources and the Environment, University of Arizona, 1064 East Lowell

12 Street, Tucson, Arizona, USA 85721; derbridge@email.arizona.edu

$13{ }^{\mathrm{d}}$ Round River Conservation Studies, 925 E 900 S, Suite 207, Salt Lake City, Utah, USA 84105;

14 kim@roundriver.org

15

16

17 Author responsible for correspondence: Jerod A. Merkle; Wyoming Cooperative Fish and

18 Wildlife Research Unit, Dept. 3166, 1000 East University Avenue, University of Wyoming,

19 Laramie, Wyoming 82071; telephone 307-399-1094; fax 307-766-5400; email

20 jmerkle@uwyo.edu. 


\section{Dietary niche partitioning among black bears, grizzly bears and wolves in a multi-prey} ecosystem

Jerod A. Merkle, Jean L. Polfus, Jonathan J. Derbridge, and Kimberly S. Heinemeyer

\section{Abstract}

Identifying mechanisms that promote coexistence of sympatric species is important for predicting ecological effects of anthropogenic change. Many caribou (Rangifer tarandus (Linnaeus, 1758)) populations are declining, and it is unclear to what extent sympatric predators consume caribou or how alternative prey affect caribou-predator relationships. We used stable isotope mixing models to estimate diets of black bear (Ursus americanus (Pallas, 1780)), grizzly bear (U. arctos (Linnaeus, 1758)), and grey wolves (Canis lupus (Linnaeus, 1758)) during early, middle, and late summer 2009-2010 in northwestern British Columbia, Canada. Although we expected wolf diet to primarily be comprised of moose (Alces alces (Linnaeus, 1758)) - as they exist at twice the density of caribou - wolf diet consisted principally of caribou, and to a lesser extent moose and beaver (Castor canadensis (Kuhl, 1820)), with little change occurring throughout summer. Black bear diet consisted mainly of vegetation and moose - shifting from moose to vegetation through summer. Grizzly bear diet consisted primarily of vegetation and moose, and did not change throughout summer. Our results demonstrate the role of dietary niche partitioning in bear and wolf coexistence, and that caribou may be primary prey for wolves in an ecosystem with relatively high moose abundance and low human development.

Key words: black bear, grizzly bear, grey wolf, caribou, Ursus americanus, Ursus arctos, Canis lupus, Rangifer tarandus, predation, stable isotope analysis, carbon, nitrogen, niche, diet, trophic relations 
44

\section{INTRODUCTION}

Identifying the mechanisms that promote coexistence of sympatric species at the same trophic level is essential to understanding and conserving biodiversity. As anthropogenic influences (including climate change) bring about alternative ecological states (Barnosky et al. 2012), interspecific dynamics will likely play an important role in ecosystem responses including whether a species is resilient or vulnerable to change (Post 2013). Although a number of mechanisms have been purported to explain coexistence among species within a trophic level (Schoener 1974), most research has focused on how species partition resources along axes of diet, space, and time (Brown 1989). In general, coexistence appears to be driven by selection for one or more of the following traits: differential consumption of prey species and prey sizes (Karanth and Sunquist 1995), differential use of habitats and space (Palomares et al. 1996), and different temporal activity patterns (Fedriani et al. 1999).

A number of different methods exist to quantify resource partitioning (e.g., gut content, scat analysis), but non-invasive sampling methods coupled with innovative technologies have resulted in fruitful contributions to understanding trophic interactions. The analysis of carbon $\left(\delta^{13} \mathrm{C}\right)$ and nitrogen $\left(\delta^{15} \mathrm{~N}\right)$ stable isotopes based on hair and tissue samples is a robust method for determining the relative contribution of different foods to a consumer's diet (DeNiro and Epstein 1978, 1981). Notably, stable isotope analysis has been extended to assess how multiple species partition dietary resources (Hobson et al. 2000; Caut et al. 2006), as well as to understand predator-prey and other trophic relationships (Post 2002; Urton and Hobson 2005). For example, previous studies have determined grey wolf (Canis lupus (Linnaeus, 1758)) diets in multi-prey systems using stable isotope analysis of non-invasively collected guard hairs (Darimont and Reimchen 2002; Derbridge et al. 2012). Stable isotope analyses can also identify the suite of 
67 predators preying upon a given species and potentially how such predation is partitioned through

68 time - providing important insight into prey species of conservation concern.

Forest-dwelling caribou (Rangifer tarandus (Linnaeus, 1758)) that occur in boreal forests

70 and mountainous regions are experiencing significant population declines (Vors and Boyce

71 2009; Festa-Bianchet et al. 2011). Although the ultimate reason for the declines can be attributed

72 to habitat alterations from resource extraction activities (Festa-Bianchet et al. 2011), the

73 proximate mechanisms behind the declines can be indirect and complex. To reduce the risk of

74 detection by predators, forest-dwelling caribou use an isolation strategy to spatially segregate

75 themselves from other prey species and conspecifics (Stuart-Smith et al. 1997; James et al.

76 2004). Yet, evidence suggests that predation can significantly limit caribou populations (Stuart-

77 Smith et al. 1997; Bergerud and Elliott 1998). Resource extraction activities can alter caribou-

78 predator relationships by providing linear features (e.g., logging roads, seismic lines) that aid

79 wolf movement (Wittmer et al. 2007; Peters et al. 2013; Losier et al. 2015). For example, in

80 northeastern Alberta, James and Stuart-Smith (2000) found that caribou have higher risk of

81 predation from wolves near linear features, which may have low human use, but are

82 preferentially used by wolves, resulting in increased travel efficiency and caribou detections.

83 Further, an increase in young seral forests following human habitat alterations can enhance

84 moose (Alces alces (Linnaeus, 1758)) and wolf populations and increase caribou vulnerability to

85 predation through the mechanism of apparent competition (Seip 1992; DeCesare et al. 2010).

86 Even a small increase in predation through altered spatial relationships between caribou,

87 alternative prey, and shared predators could lead to population level effects in populations with

88 low growth rates (Seip 1992; James et al. 2004; Hervieux et al. 2014). 
The northern mountain caribou Designatable Unit (COSEWIC 2011) occurs in local

90 populations throughout the Yukon, Northwest Territories, and northwestern British Columbia

91 (BC), and was listed as a species of special concern in 2014 by the Committee on the Status of

92 Endangered Wildlife in Canada (COSEWIC; COSEWIC 2014). Our current knowledge of why

93 northern mountain caribou populations are declining is incomplete, mainly because a lack of

94 information about the complex dynamics of multi-prey, multi-predator ecosystems (COSEWIC

95 2014). For instance, in east-central Yukon, Hayes et al. (2000) found that moose composed 94\%

96 of the biomass of ungulates killed by wolves, and wolves did not prey heavily on caribou even

97 when caribou outnumbered moose. Similarly, in the North Columbia Mountains of southeastern

98 BC, Stotyn (2008) found that the relative proportion of caribou within wolf diet was not related

99 to caribou density. Rather, caribou may use spatial or temporal refuges to avoid wolves, or

100 wolves may preferentially kill moose and other prey items. In northeastern Alberta, Latham et al.

101 (2013) found that during summer wolf selection for areas used by beaver led to an increase in

102 spatial overlap with caribou. Further, understanding predation on caribou is complicated by the

103 presence of other predators (i.e., bears). It is well known that black (Ursus americanus (Pallas,

104 1780)) and grizzly (U. arctos (Linnaeus, 1758)) bears can be important predators of neonatal

105 ungulates (Zager and Beecham 2006; Barber-Meyer et al. 2008), including caribou (Ballard

106 1992, 1994; Adams et al. 1995; Young Jr and McCabe 1997).

107

In many populations of forest-dwelling caribou it is still unclear which predators

108 influence (or potentially limit) prey populations and how the levels of human development and

109 alternative prey species affect these predator-prey interactions. In this study we used Bayesian

110 stable isotope mixing models to reconstruct the dietary differences and overlap of black bears,

111 grizzly bears, and grey wolves during early, middle, and late summer in northwestern BC - an 
112 area characterized by relatively low levels of human development (including logging and

113 resource extraction). We sampled hair from these predators and their potential prey species, and

114 also plant species important for bears. Based on previous literature, caribou are generally a

115 secondary prey item because they are typically less numerous than moose. Our study area is no

116 exception as there exists an estimated 777 caribou and 1,971 moose (Taku River Tlingit First

117 Nation and Province of British Columbia 2010; Marshall 2015; see study area section for

118 details). Thus, we expected that compared to moose, caribou would comprise relatively low

119 proportions of predator diets. We also expected that bear diet would reflect predation on ungulate

120 neonates in early summer, and then shift to a primarily vegetarian diet during late summer when

121 soft plant mast becomes available (Munro et al. 2006). Our study is unique as it provides a

122 comprehensive analysis of the diets of three sympatric predators (i.e., a multi-predator system)

123 with a specific eye towards predation on caribou during the neonatal stage when bear predation

124 is important.

125 STUDY AREA

This study took place within the traditional territory of the Taku River Tlingit First

127 Nation in northwestern BC, extending into southern Yukon Territory (Figure 1). The 11,594 km²

128 study area primarily falls within the boreal mountains and plateaus ecoregion (Environment

129 Canada 2005), characterized by high peaks, broad plateaus, and wide valleys with elevations

130 ranging from 660 to $2000 \mathrm{~m}$. Human development in the study area consists of the town of Atlin

131 with approximately 350 residents, and a total of approximately $1250 \mathrm{~km}$ of roads (including

132 approximately $100 \mathrm{~km}$ of paved roads, $400 \mathrm{~km}$ of unimproved gravel and dirt roads and an

133 additional $750 \mathrm{~km}$ of All-Terrain Vehicle trails; overall road density of $0.11 \mathrm{~km} / \mathrm{km}^{2}$ ). All paved

134 roads and most unimproved roads are disproportionately found at low elevations resulting from a 
135 long history of placer mining and mineral exploration in the region. Current mining activity is 136 focused on stream drainages which has been an important economic driver in the region for over 137100 years (Taku River Tlingit First Nation and Province of British Columbia 2011). However, 138 All-Terrain Vehicle trails provide access across the study area into higher elevation subalpine 139 and alpine areas. There is no large-scale commercial logging; however, there is some small-scale 140 local timber operations for home building and mine development (Taku River Tlingit First 141 Nation and Province of British Columbia 2011). The climate is typified by long, cold winters and short, warm summers. The mean 143 summer temperature is $10^{\circ} \mathrm{C}$ and the winter mean is $-15^{\circ} \mathrm{C}$ (Environment Canada 2005). Annual 144 precipitation in the study area is approximately $33 \mathrm{~cm}$ resulting in an average late winter snow 145 depth of $49.5 \mathrm{~cm}$ (Atlin snow station 1964-2003). Low to mid-elevation boreal forests include a 146 mix of lodgepole pine (Pinus contorta var. latifolia Engelm. ex S. Watson), subalpine fir (Abies

147 lasiocarpa (Hook.) Nutt.) and white and black spruce (Picea glauca (Moench) Voss and $P$. 148 mariana (Mill.) Britton, Sterns and Poggenb.). Deciduous stands of trembling aspen (Populus tremuloides Michx.), black cottonwood (Populus balsamifera trichocarpa (Torr. and A. Gray) 150 Brayshaw), alder (Alnus tenuifolia (Nutt.) Breitung) and willow (Salix spp. L.) occupy valley 151 bottoms and riparian areas. The understory commonly consists of low shrubs and lichen species 152 including various reindeer (Cladonia spp.), pixie-cup (Cladonia spp.), foam (Stereocaulon spp.) 153 and Iceland lichens (Cetraria spp.) and numerous forbs and mosses. White spruce and subalpine 154 firs dominate the subalpine from 850-1500 $\mathrm{m}$ transitioning at mid elevations into krummholz 155 where thick knee-high spreads of willow and dwarf birch (Betula glandulosa Michx.) dominate. 156 Alpine zones (above $1500 \mathrm{~m}$ ) consist of extensive areas of rolling alpine tundra characterized by 157 sedge (Carex spp. L.) and altai fescue (Festuca altaica Trin.) dominated meadows. Mountain 
158 heather (Cassiope spp. D. Don), crowberry (Empetrum nigrum L.), mountain avens (Dryas spp.

159 L.) and lichen communities are also common.

The Atlin northern mountain caribou population relies heavily on low-elevation mature

161 lodgepole pine forests in the winter and high elevation alpine and subalpine forest in the summer

162 (Polfus et al. 2011; Polfus et al. 2014). Aerial surveys indicate that although the nearby Yukon

163 caribou populations appear to be increasing in abundance (calf:female ratios for the Carcross and

164 Yukon woodland caribou herds are 27:100 and 26:100, respectively; Hegel 2013), the Atlin

165 population has maintained a stable or decreasing population with a low calf recruitment of $21 \pm 3$

166 calves: 100 females (Taku River Tlingit First Nation and Province of British Columbia 2010).

167 The adjacent Carcross herd is hunted within its range in British Columbia, but hunting is closed

168 in the Yukon and voluntarily suspended by First Nations. British Columbia currently allows a

169 limited entry hunt and guide-outfitter quota of 10 males/year in the Atlin population. There are

170 an estimated $777 \pm 132$ caribou in the Atlin population (Taku River Tlingit First Nation and

171 Province of British Columbia 2010), and 1,971 \pm 464 moose (estimated from a 2015 stratified

172 random block survey of moose in the Atlin region yielding $0.17 \pm 0.04$ moose $/ \mathrm{km} 2$; Marshall

173 2015). Other ungulates in the area include and mountain goats (Oreamnos americanus

174 (Blainville, 1816)) and Stone's sheep (Ovis dalli stonei (J. A. Allen, 1897)) in alpine zones.

175 Apart from grizzly bears, black bears, and wolves, the predator community relative to ungulates

176 includes wolverines (Gulo gulo (Linnaeus, 1758)), and lynx (Lynx canadensis (Kerr, 1792)).

177 METHODS

\section{Sample collection}

To estimate dietary differences and overlap between black bears, grizzly bears, and

180 wolves, we collected hair samples using non-invasive hair snares set up throughout the study 
181 area during the summers (June-August) of 2009-2010. Wolves have one annual molt that begins

182 in late spring when the old coat is shed and new hair grows until late fall (Darimont and

183 Reimchen 2002). Bears begin molt in late spring after emerging from the den and continue into

184 the fall (Jacoby et al. 1999; Stotyn et al. 2007). We collected wolf hair with non-invasive rub

185 pads constructed following Ausband et al. (2011). The hair snares were scent lured using Forsyth

186 wolf call, Forsyth wolf gland, Forget's cachotier call (canine), freshwater fish oil, and

187 commercial wolf urine purchased from Halford's (Edmonton, Alberta, Canada). We set up hair

188 snares in areas identified as movement corridors based on field observations (tracks and scat) and

189 on information from local hunters and trappers who had knowledge of animal locations.

We collected bear hair from rub trees and barbed wire corral stations with a non-reward

191 scent lure following Boulanger and McLellan (2001). We placed corral stations near rub trees

192 and along movement corridors that allowed repeated access over the course of the summer. Our

193 lure was a mixture of salmon oil, beaver castor and Forget's cachotier call (canine). We also

194 opportunistically collected bear hair from rub trees that were encountered in the field. We set up

195 rub pads and corral stations at the end of June and early July, and checked and re-lured the sites

196 approximately every ten days until mid-August.

197

During summers 2009-2010, we also opportunistically collected hair from prey species at

198 predator kill sites found in the field, from the ground near hunting camps, and from local hunters

199 and trappers. We collected guard hairs with tweezers and placed them in manila envelopes,

200 which we then placed in plastic bags with desiccant beads to prevent moisture build-up. The

201 Kluane Ecological Monitoring Project in the Yukon provided snowshoe hare (Lepus americanus

202 (Erxleben, 1777)) hair samples collected during annual monitoring efforts. The Museum of

203 Southwestern Biology at the University of New Mexico provided small mammal hair samples 
204 from least chipmunk (Tamias minimus (Bachman, 1839)) and northern red backed voles (Myodes 205 rutilus (Pallas, 1779)) collected within or immediately adjacent to our study area.

We also collected samples from 15 plant species known to be important to bear diet (Fuhr and Demarchii 1990; Nielsen et al. 2004). We collected above-ground foliage from horsetail (Equisetum spp. L.), dandelion (Taraxacum spp. F.H. Wigg.), clover (Trifolium spp. L.), sedges (Carex spp.), fescue (Festuca spp.), cow parsnip (Heracleum lanatum Michx.), lupine (Lupinus spp. L.), rose (Rosa spp. L.), arrowleaf (Senecio triangularis Hook.), and berries from

211 kinnikinnick (Arctostaphylos uva-ursi (L.) Spreng.), soapberry (Shepherdia Canadensis (L.)

212 Nutt.), blueberry (Vaccinium caespitosum Michx.), and crowberry (Empetrum nigrum L.).

213 Vegetation samples were desiccated in a drying oven and ground into a fine powder for stable 214 isotope analysis.

\section{Stable isotope analysis}

We cleaned all hair samples of surface oils in a 2:1 chloroform:methanol solution for 24

217 hours and dried them at low heat for 24 hours. Predator guard hairs were cut into three sections 218 (root, middle, and tip sections) representative of different seasons during hair growth (Milakovic 219 and Parker 2011): root section reflects most recent growth (hereafter termed late summer), the 220 middle section reflects earlier growth (mid-summer) and the tip section reflects earliest hair 221 growth (early summer). The rate and timing of hair growth is expected to differ between 222 individual bears (B. Milakovic pers. comm.). Thus, we split bear and wolf hairs into three equal 223 sections based on each guard hair length so that each section was representative of a specific 224 time period relative to each individual. 
227 continuous flow isotope-ratio mass spectrometer. When enough hair was available, replicates

228 were included approximately every 8-12 samples to check instrument precision. Stable isotopes

229 are expressed in delta notation $(\delta)$ in parts per thousand (\%o) following standard methods (Post

230 2002). Based on repeated internal standards, precision was better than \pm 0.10 for $\delta^{13} \mathrm{C}$ and \pm 0.2

231 for $\delta^{15} \mathrm{~N}$.

232 DNA analysis

Prior to stable isotope analyses, a sub-sample of hairs from each predator sample was sent

234 to the USFS Rocky Mountain Research Station (Missoula, Montana) to identify species

235 (mtDNA) and individuals (microsatellites). We used a previously developed panel of nine

236 variable loci for bears and eight variable loci for wolves. To avoid pseudoreplication within our

237 sample, subsequent stable isotope analyses were only conducted on a single sample from each

238 unique individual sampled during the study. When individuals were identified more than once

239 during the study we randomly selected one of the samples for analysis.

240 Stable isotope mixing models

We used a Bayesian mixing model approach (Phillips 2012) to determine the proportions

242 of prey in the diets of black bears, grizzly bears, and wolves for each of the three seasons (early,

243 middle, and late summer). Mixing models estimate the proportion $p$ of each food source $s$ (from

2441 to $k$ different sources) in the diet of each consumer $X$ (from 1 to $i$ individual consumers), based

245 on fractionation values $c$ for each isotope of interest (from 1 to $j$ different isotopes). As

246 formulated by Jackson et al. (2009), the form of the mixing model was:

$$
X_{i j}=\sum_{k=1}^{k} p_{k}\left(s_{j k}+c_{j k}\right)+\varepsilon_{i j}
$$


where $X_{i j}$ was the observed isotope value $j$ of individual consumer $i$ based on $k$ sources.

248 The residual error $\varepsilon_{i j}$ described additional inter-observation variance not described by the model (Jackson et al. 2009). The model distributions were: $s_{j k} \sim \operatorname{Normal}\left(\mu_{j k}, \omega_{j k}^{2}\right), \mathrm{c}_{j k} \sim \operatorname{Normal}\left(\lambda_{j k}, \tau_{j k}^{2}\right)$, $\varepsilon_{i j} \sim \operatorname{Normal}\left(0, \sigma_{j}^{2}\right)$. Because there was no previous literature documenting diets of all three predator species within the same predator-prey complex as in our study area, we specified uninformative priors (i.e., a Dirichlet distribution with al $\alpha_{k}$ in each analysis equal to 1 ) for all analyses.

We estimated proportions of each food source $p_{k}$ using standard Markov chain Monte 255 Carlo simulations with a burn-in of 50,000 iterations. We generated posterior samples using 25615,000 iterations of the model and a thinning rate of 15 . We chose the number of iterations by 257 calculating the Gelman and Rubin convergence diagnostic (Brooks and Gelman 1998) and 258 increasing the number of iterations until the statistic was $<1.1$. Parameterization of the mixing 259 model was conducted in R 3.2 (R Core Team 2014) and JAGS (Plummer 2003). wolves that were fed a known diet $\left(\right.$ mean $\pm \mathrm{SD}, \Delta^{13} \mathrm{C}(\%)=1.972 \pm 0.705, \Delta^{15} \mathrm{~N}(\%$ o $)=3.04 \pm$ $2620.313)$. For bears, we used fractionation values for nitrogen $\left(\Delta^{15} \mathrm{~N}(\%)=4.76 \pm 0.45\right.$ for vegetation and $4.5 \pm 0.45$ for meat) from Hilderbrand et al. (1996), and for carbon $\left(\Delta^{13} \mathrm{C}(\%)=2\right.$

$264 \pm 1$ ) from Mowat and Heard (2006) and Ben-David et al. (2004), as used on other stable isotope 265 diet studies of bears (e.g., Merkle et al. 2011). must have isotopically distinct stable isotope values when reconstructing animal diets (Phillips 2012). We tested for isotopically distinct stable isotope values among our prey items using 
270 Welch's two sided $t$-tests and two-sided Wilcoxon rank sum test with continuity correction for

271 carbon and nitrogen isotopes separately, and a multiple analysis of variance (MANOVA) for

272 carbon and nitrogen isotopes simultaneously (See Supplementary Table S1 for results).

273 Our intent was to identify the main components of bear and wolf diets, while also being

274 able to compare across the three predators. Thus, we only focused on large mammals, and did

275 not include any potential prey smaller than beaver (Castor canadensis (Kuhl, 1820)). Indeed,

276 little to no mammals smaller than beaver were found in wolf scats in a near-by study area

277 (Milakovic and Parker 2011), and wolf diet is known to be mainly composed of large mammals

278 (Merkle et al. 2009; Derbridge et al. 2012). Additionally, when bear diet during summer includes

279 meat it is often from neonatal ungulates (Mowat and Heard 2006).

We included moose and beaver as a potential dietary sources as moose are common in the

281 study area and beaver can be an important diet component for wolves (Potvin et al. 1988).

282 Because we were interested in quantifying the proportion of caribou in predator diet, caribou was

283 also included as a prey item in our mixing models for all three predator species. The isotope

284 signature of caribou was significantly different from all other species, except for Stone's sheep.

285 We assumed that Stone's sheep were rarely depredated by wolves and bears given the low

286 density of the local population (approx. 80 in the study area; Taku River Tlingit First Nation and

287 Province of British Columbia 2010), and Stone's sheep generally avoid areas where wolves and

288 bears are found during summer and fall (Walker et al. 2007). Thus, we did not include Stone's

289 sheep, nor combine their isotope values with caribou, in the stable isotope analysis. Nonetheless,

290 we note that it does appear that wolf predation is a leading cause of mortality in some Stone's

291 sheep populations (Bergerud and Elliott 1998), and by excluding Stone's sheep, a small

292 proportion of predator diet attributed to caribou may be due to predation on the isotopically 
293 similar Stone's sheep. We also excluded mountain goats from the analysis because of their

294 relatively low density in our study area (Environment Yukon 2011) and because no study to our

295 knowledge has suggested that mountain goats are an important dietary component of wolves or

296 bears. Finally, for black bear and grizzly bear diets we also included vegetation (Hobson et al.

297 2000; Mowat and Heard 2006). There was considerable overlap in $\delta^{13} \mathrm{C}$ and $\delta^{15} \mathrm{~N}$ of the 13 plant

298 species we sampled, so we sub-sampled four random plant isotope values from each plant type

299 and estimated a general vegetation baseline for the study area by calculating the mean and SD of

300 all of the combined vegetation isotope values.

301 RESULTS

302 DNA analysis

303 During summers 2009-2010 we collected 127 bear and 41 wolf hair samples. Due to

304 sample quantity and quality only the largest samples of complete wolf and bear hairs were sent to 305 the lab for genetic analysis. DNA extractions were performed on 42 bear hair samples and 18 306 wolf hair samples from 2009, and 22 bear hair samples and 13 wolf hair samples from 2010. We 307 obtained mtDNA for species identification from 47 of the 64 suspected bear samples (73\%); 30 308 samples were from grizzly bear, 16 samples were from black bear, and one sample was a mix of 309 grizzly and black bear. We obtained mtDNA for species identification from 29 of the 31 wolf 310 samples (94\%); all were identified as C. lupus. After obtaining high quality DNA that allowed for individual identification using the 312 microsatellite panel, we identified 13 individual grizzly bears in 2009, and four in 2010. One 313 grizzly bear was identified in both 2009 and 2010. We identified six individual black bears in 3142009 , and seven in 2010. One black bear was identified in both 2009 and 2010. We identified 10 
315 individual wolves in 2009, and five in 2010. Three individual wolves were identified in both $316 \quad 2009$ and 2010.

\section{Stable isotope mixing models}

We obtained $\delta^{13} \mathrm{C}$ and $\delta^{15} \mathrm{~N}$ estimates for the 12 known black bear samples, 16 known grizzly bear samples, and 12 known grey wolf samples (sample sizes do not include individuals captured in both 2009 and 2010). For prey species, stable isotope estimates were derived from moose, caribou, mountain goat, Stone's sheep, beaver, snowshoe hare, least chipmunks, northern

322 red-backed voles, and 13 plant species (Figure 2, Supplementary Table S2). Our replicate

323 analysis $(n=7)$ suggested that instrument precision at the stable isotope facility was relatively

324 high, and that there was little to no measurement/calculation error associated with estimating $325 \quad \delta^{13} \mathrm{C}$ and $\delta^{15} \mathrm{~N}($ Supplementary Fig. S1).

In general, compared to both bear species, the diet of wolves was more enriched in both

327 nitrogen and carbon. Black bear and grizzly bear $\delta^{13} \mathrm{C}$ and $\delta^{15} \mathrm{~N}$ were relatively similar to each

328 other. Further, $\delta^{13} \mathrm{C}$ and $\delta^{15} \mathrm{~N}$ for all predators were similar across early, middle, and late

329 summer, except for the root section of black bear hair (representing late summer diet) which was

330 more depleted in nitrogen compared to other periods of black bear and grizzly bear diet (Figure

$3313)$.

Based on Bayesian stable isotope mixture models, wolf diet consisted principally of caribou (mean of $50 \% \pm 0.10 \mathrm{SD}$ of diet), and to a lesser extent beaver $(21 \% \pm 0.12)$ and moose

$334(29 \% \pm 0.09)$, with little change occurring over the course of the summer (Figure 4). Black bear

335 diet consisted mainly of vegetation $(43 \% \pm 0.10)$ and moose $(31 \% \pm 0.16)$, and to a lesser extent

336 beaver $(14 \% \pm 0.10)$ and caribou $(12 \% \pm 0.09)$, with a clear shift from a diet of moose and

337 vegetation in early summer, to a diet of mostly vegetation in late summer (Figure 4). Similar to 
338 black bear, grizzly bear diet consisted mainly of vegetation $(42 \% \pm 0.08)$ and moose $(28 \% \pm$

$3390.16)$ and to a lesser extent beaver $(16 \% \pm 0.11)$ and caribou $(15 \% \pm 0.10)$; however, we

340 observed little change in diet occurring over the course of the summer (Figure 4).

341 DISCUSSION

342 We quantified diet of three sympatric predators in a multi-prey ecosystem over the course

343 of summer. As expected, both bear species primarily consumed vegetation and moose (the most

344 abundant large mammalian prey in our study area), and to a lesser extent caribou and beaver. As

345 expected, over the course of the summer, black bears shifted from a diet comprised of meat and

346 vegetation to a diet mainly comprised of vegetation. This was not the case for grizzly bears,

347 where moose and vegetation were consistently consumed throughout the summer. Unexpectedly,

348 our results suggest that wolves primarily consumed caribou, and to a lesser extent beaver and

349 moose, even though caribou density is approximately half that of moose density in our study area

350 (Taku River Tlingit First Nation and Province of British Columbia 2010). Our results

351 demonstrate that black bear, grizzly bear, and wolf coexistence is driven in part by strong dietary

352 niche partitioning, and that wolves may be consuming more caribou than expected based on

353 availability of prey.

354 The partitioning of diet among black bears, grizzly bears, and wolves may not be solely

355 driven by diet selection, but also by spatial separation (Hobson et al. 2000). During summer,

356 caribou select for high elevation, broad mountain plateaus (Polfus et al. 2011; Polfus et al. 2014),

357 whereas moose select valley bottoms consisting of deciduous and riparian vegetation (Peters et

358 al. 2013). It is plausible that the underlying diet differences between bears and wolves that we

359 observed was that wolves spent significant time in high elevation areas, and bears spent

360 significant time in low elevation areas. Indeed, Whittington et al. (2011) found that in Banff and 
361 Jasper National Parks wolves spend the most time at high elevations resulting in the highest

362 encounter risk for caribou. Further, in Quebec, caribou that avoid areas that wolves use tend to

363 select areas where black bears occur, consequently exposing themselves to higher predation by

364 bears (Leblond et al. 2016). Whether driven by space use or not, diet partitioning appears to

365 allow these sympatric predators to minimize competition and coexist in a multi-predator, multi-

366 prey ecosystem.

Our results confirm that ungulates are an important component of bear diet in early

summer. As summer progresses, however, both bear species typically consume relatively large amounts of vegetation, especially as soft mass becomes available in late summer (Raine and Kansas 1990; McLellan and Hovey 1995; Munro et al. 2006). We observed this typical shift

371 from meat to vegetation in the diet of black bears, which matched high relative availability of

372 soft mast later in summer in our study area. However, our results indicated that grizzly bears

373 foraged on both meat and vegetation throughout the summer. Milakovic and Parker (2013)

374 reported that meat was a significant part of grizzly bear diet in northern BC throughout the

375 summer, and even noted a relative increase in meat consumption compared to vegetation from

376 early to late summer. They attributed the result to increased consumption of elk - a species that

377 does not exist in our study area (Milakovic and Parker 2013). In accordance with our results,

378 Fortin et al. (2013) found that black bears indeed consumed less meat than grizzly bears in

379 Yellowstone National Park. Decreased black bear predation on moose likely occurs as moose

380 calves become too large and fast to capture as summer progresses. Further, grizzly bears may be

381 more effective than black bears at obtaining and competing for ungulate carcasses killed by

382 wolves over the course of the summer (Smith et al. 2003). Both reasons suggest mechanisms

383 behind dietary niche portioning among the three predators. 
Caribou were the most important prey item for wolves throughout the summer. This

result is somewhat surprising as it suggests that wolves are selecting for caribou even though moose density is twice that of caribou in our study area. Previous studies have suggested that in multi-predator prey systems, moose are generally the primary prey of wolves and caribou are more likely to be an opportunistic or alternative prey (Wittmer et al. 2005; Wittmer et al. 2007). However, it has also been shown that availability alone may not determine primary prey of wolves, which sometimes exhibit preference for particular prey species (Huggard 1993; Dale et al. 1995). Prey switching can also occur as prey abundance varies over time (Garrott et al. 2007), and variation in diet among packs within a population has been reported (Kunkel et al. 2004; Derbridge et al. 2012). Regardless of prey species, vulnerability to predation is the most consistent factor determining wolf predation (Mech and Peterson 2003). Since wolves are more likely to be found alone, in pairs, or in small groups during the summer (Fuller et al. 2003), caribou may be a more vulnerable or profitable prey item (in terms of energy/handling time) than moose which are generally 2-3 times larger than caribou. This greater profitability was noted by Dale et al. (1995) who suggested relative vulnerability of caribou explained why they were selected by wolves even when moose were more abundant in Alaska. We also note that our results provide some evidence that five of the 12 individual wolves we sampled likely preyed mainly on caribou (i.e., their isotope signatures fall exactly on top of the isotopic signature of caribou; see Supplementary Fig. S2), whereas isotopic signatures of the other wolves were closer to the signatures of moose and beaver - potentially explaining how the overall average consumption of caribou was so high.

Predation rates, predator preferences, and mortality risks for prey may be strongly impacted by the level of habitat modification in a landscape (Schlaepfer et al. 2002). For 
407 example, in Alberta and Quebec anthropogenic conversion of habitats that favor moose appears

408 to result in larger wolf populations and increased wolf predation risk on caribou via apparent

409 competition (Seip 1992; DeCesare et al. 2010; Losier et al. 2015). Further, as human

410 development increases, the spatial overlap of caribou and moose as well as caribou mortality

411 from wolves tends to increase (Peters et al. 2013). Our study system on the other hand, has not

412 experienced extensive habitat conversion (e.g., no significant logging) that impacts other regions

413 that support caribou-moose-wolf dynamics (Johnson et al. 2015; Losier et al. 2015). The

414 predominant human disturbance in the Atlin area is placer mining along creek bottoms of two

415 drainage systems within the study area. The study area has only one main road (Highway 7) that

416 connects Atlin to the Alaska Highway and the city of Whitehorse in the Yukon Territory.

417 However, because of historical prospecting, our study area does have a rather high density of low

418 use roads. There are approximately $100 \mathrm{~km}$ of paved roads, $400 \mathrm{~km}$ of unimproved gravel and

419 dirt roads and an additional $750 \mathrm{~km}$ of All Terrain Vehicle trails in the study area. These roads

420 likely provide wolves with easy access to alpine plateaus and caribou summer habitats. If wolf

421 predation is enhanced by linear features on the landscape (Whittington et al. 2011), it is likely

422 that wolf predation rates on caribou would be increased by even moderate levels of linear

423 features. Further, caribou have been shown to avoid linear developments (and other human

424 landscape alterations including placer mines and cabin sites) in our study area during the

425 summer, even though human presence on the road network is relatively low (Polfus et al. 2011).

426 Therefore, as others have suggested (e.g., Whittington et al. 2011), decommissioning roads and

427 other habitat restoration projects may be a future management strategy to help minimize declines

428 in woodland caribou populations. 
It is important to note that the results of our stable isotope analysis cannot be projected

430

431

432

433

434

435

436

437

438

439

440

441

442

443

444

445

446

447

448

449

450

451

during winter months when bears are inactive, as it is unknown in our study area whether wolves switch to moose as their main prey during winter. Such seasonal variation in predation by wolves on moose and caribou must be taken into account when determining the total influence of multiple predators on prey populations. For example, Metz et al. (2012) found that the species composition of wolf predation events varies by season in Yellowstone National Park, and Peters et al. (2013) found that the strength of resource separation between moose and caribou in Alberta depends on season.

Wolves, grizzly bears, and black bears have coexisted, along with a suite of large ungulate prey (that includes caribou), for thousands of years in North America. Our study sheds light on how these three predators partition resources to coexist, suggesting that bears consume mainly moose and vegetation, whereas wolves consume mainly caribou during summer. Our study also reveals that caribou are the primary prey for wolves during summer in an ecosystem where moose are more abundant than caribou and relatively little human development has occurred compared to the habitat of other forest-dwelling caribou populations across their range.

Together these findings suggest that dietary niche partitioning allows for these multi-prey, multipredator ecosystems to exist, and that these ecosystems are challenging to understand with processes such as apparent competition, prey selectivity, and redundancy among interspecific interactions all at play. No single management strategy (e.g., habitat enhancements, decrease density of a single predator or preferred prey of a predator) will likely result in significant, longterm changes to these communities and it appears successful caribou conservation will require a multi-faceted approach that includes curbing human development and native habitat restoration. ACKNOWLEDGEMENTS 
452 This work was supported by the Government of Canada Aboriginal Fund for Species at Risk, 453 Taku River Tlingit First Nation (TRTFN), Round River Conservation Studies (RRCS), and a 454 U.S. Department of Agriculture National Institute of Food and Agriculture postdoctoral 455 fellowship (grant award \# 2014-01928) awarded to JAM. The partnership between the TRTFN 456 and RRCS facilitated the development of funding proposals, project management, reporting and 457 implementation. We appreciate mapping support from Julia Smith and help with field work from 458 Myranda Simpson, Morgane Stehelin-Holland, Jerry Jack, Phillip Tizya and Mark Connor. We 459 also thank Doug Milek, Heidi Larsen, Rick Tingey, Chris Lockhart, Claire Polfus, Susie Dain460 Owens, Leah Larsen, Jeff Muntifering, Bryan Evans, Gavin Noyes, Julian Griggs, Kevin 461 Cannaday, Basilia Andoroone Shivute, Drew Chambers, Megan Mitchell, Matt Stone, Maggie 462 Harris, Jake Robert Claro, Rebecca Guiao, Emily Moffitt, Ethan Rubenstein, Leif Olson, Hannah 463 Tannebring and Kate Shlepr for help in the field. Elizabeth Hofer and Frank Doyle provided 464 snowshoe hare hair from the Kulane snowshoe hare project. Small mammal samples were 465 provided by the mammal collection of the Museum of Southwestern Biology at the University of 466 New Mexico by Joseph Cook (MSB:Mamm:12656). Additional samples were provided by Earl 467 Carlson, Sophie van den Bergh, Hans Berg and Norm Graham. Genetic analysis was conducted 468 by Kristine Pilgrim and Michael Schwartz at the USFS Rocky Mountain Research Station. Cara 469 Nelson, Lisa Eby, and Matthew Wilson of University of Montana shared work space and 470 equipment. We thank Rebecca Fletcher for help processing samples for isotope analysis. Advice 471 was provided by Brendan Oates, Brian Milakovic and Justin Yeakel.

472 LITERATURE CITED

473 Adams, L.G., Singer, F.J., and Dale, B.W. 1995. Caribou calf mortality in Denali national park, 474 Alaska. J. Wildl. Manage. 59: 584-594. doi: 10.2307/3802467. 
475 Ausband, D.E., Young, J., Fannin, B., Mitchell, M.S., Stenglein, J.L., Waits, L.P., and Shivik,

476

477

478

479

480

481

482

483

484

485

486

487

488

489

490

491

492

493

494

495

J.A. 2011. Hair of the dog: obtaining samples from coyotes and wolves noninvasively. Wildl. Soc. Bull. 35(2): 105-111. doi: 10.1002/wsb.23.

Ballard, W.B. 1992. Bear predation on moose: a review of recent North American studies and their management implications. Alces, 1: 162-176.

Ballard, W.B. 1994. Effects of black bear predation on caribou-a review. Alces, 30: 25-35.

Barber-Meyer, S.M., Mech, L.D., and White, P.J. 2008. Elk Calf Survival and Mortality

following Wolf Restoration to Yellowstone National Park. Wildl. Monogr. 169: 1-30. doi: $10.2193 / 2008-004$.

Barnosky, A.D., Hadly, E.A., Bascompte, J., Berlow, E.L., Brown, J.H., Fortelius, M., Getz, W.M., Harte, J., Hastings, A., and Marquet, P.A. 2012. Approaching a state shift in Earth's biosphere. Nature, 486: 52-58. doi:10.1038/nature11018.

Ben-David, M., Titus, K., and Beier, L.R. 2004. Consumption of salmon by Alaskan brown bears: a trade-off between nutritional requirements and the risk of infanticide? Oecologia, 138: 465-474. doi: 10.1007/s00442-003-1442-x.

Bergerud, A., and Elliott, J. 1998. Wolf predation in a multiple-ungulate system in northern British Columbia. Can. J. Zool. 76: 1551-1569. doi: 10.1139/z98-083.

Boulanger, J., and McLellan, B. 2001. Closure violation in DNA-based mark-recapture estimation of grizzly bear populations. Can. J. Zool. 79: 642-651. doi: 10.1139/z01-020.

Brown, J.S. 1989. Coexistence on a seasonal resource. Am. Nat. 133: 168-182. doi: $10.1086 / 284908$. 
496 Caut, S., Roemer, G.W., Donlan, C.J., and Courchamp, F. 2006. Coupling stable isotopes with 497 498 499 500 501 502 bioenergetics to estimate interspecific interactions. Ecol. Appl. 16: 1893-1900. doi: $10.1890 / 1051-0761$.

COSEWIC. 2011. Designatable units for caribou (Rangifer tarandus) in Canada. Committee on the Status of Endangered Wildlife in Canada, Ottawa, Ontario, Canada.

COSEWIC. 2014. COSEWIC assessment and status report on the Caribou Rangifer tarandus, Northern Mountain population, Central Mountain population and Southern Mountain population in Canada. Committee on the Status of Endangered Wildlife in Canada. Ottawa. xxii +113 pp.

505 506 507 508 509 510

Dale, B.W., Adams, L.G., and Boyer, R.T. 1995. Winter wolf predationin a multiple ungulate prey system, Gates of the Arctic National Park, Alaska. In Ecology and conservation of wolves in a changingworld. Edited by L.N. Carbyn and S.H. Fritts and D.R. Seip. Canadian Circumpolar Institute, Edmonton, Alberta, Canada. pp. 223-230.

Darimont, C., and Reimchen, T. 2002. Intra-hair stable isotope analysis implies seasonal shift to salmon in gray wolf diet. Can. J. Zool. 80: 1638-1642. doi: 10.1139/z02-149.

DeCesare, N., Hebblewhite, M., Robinson, H., and Musiani, M. 2010. Endangered, apparently: the role of apparent competition in endangered species conservation. Anim. Conserv. 13: 353-362. doi: 10.1111/j.1469-1795.2009.00328.x.

DeNiro, M.J., and Epstein, S. 1978. Influence of diet on the distribution of carbon isotopes in animals. Geochim. Cosmochim. Acta, 42: 495-506. doi: 10.1016/0016-7037(78)90199-0.

DeNiro, M.J., and Epstein, S. 1981. Influence of diet on the distribution of nitrogen isotopes in animals. Geochim. Cosmochim. Acta, 45: 341-351. doi: 10.1016/0016-7037(81)90244-1. 
Derbridge, J.J., Krausman, P.R., and Darimont, C.T. 2012. Using Bayesian stable isotope mixing models to estimate wolf diet in a multi-prey ecosystem. J. Wildl. Manage. 76: 12771289. doi: 10.1002/jwmg.359.

Derbridge, J.J., Merkle, J.A., Bucci, M.E., Callahan, P., Koprowski, J.L., Polfus, J.L., and Krausman, P.R. 2015. Experimentally Derived $\delta^{13} \mathrm{C}$ and $\delta^{15} \mathrm{~N}$ Discrimination Factors for Gray Wolves and the Impact of Prior Information in Bayesian Mixing Models. Plos One, 10: e0119940. doi: 10.1371/journal.pone.0119940.

Environment Canada. 2005. Narrative descriptions of terrestrial ecozones and ecoregions of Canada - boreal cordillera ecozone. Environment Canada, Ottawa, Ontario, Canada.

Environment Yukon. 2011. Mountain Goat Survey of the Southwest Yukon and Northwest British Columbia, 2007. Yukon Fish and Wildlife Branch Report TR-11-14, Whitehorse, Yukon, Canada.

Fedriani, J.M., Palomares, F., and Delibes, M. 1999. Niche relations among three sympatric Mediterranean carnivores. Oecologia, 121: 138-148. doi:10.1007/s004420050915.

Festa-Bianchet, M., Ray, J., Boutin, S., Côté, S., and Gunn, A. 2011. Conservation of caribou (Rangifer tarandus) in Canada: an uncertain future. Can. J. Zool. 89: 419-434. doi: 10.1139/z11-025.

Fortin, J.K., Schwartz, C.C., Gunther, K.A., Teisberg, J.E., Haroldson, M.A., Evans, M.A., and Robbins, C.T. 2013. Dietary adjustability of grizzly bears and American black bears in Yellowstone National Park. J. Wildl. Manage. 77: 270-281. doi: 10.1002/jwmg.483.

Fuhr, B.L., and Demarchii, D.A. 1990. A methodology for grizzly bear habitat assessment in British Columbia. British Columbia Ministry of Environment, Wildlife Branch, Victori, British Columbia. 
541 Fuller, T.K., Mech, L.D., and Cochrane, J.F. 2003. Wolf population dynamics. In Wolves:

542

543

544

545

546

547

548

549

550

551

552

553

554

555

556

557

558

559

560

561

562 behavior, ecology, and conservation. Edited by L.D. Mech and L. Boitani. University of Chicago Press, Chicago, Illinois, USA. pp. 161-191.

Garrott, R.A., Bruggeman, J.E., Becker, M.S., Kalinowski, S.T., and White, P.J. 2007. Evaluating Prey Switching in Wolf-Ungulate Systems. Ecol. Appl. 17: 1588-1597. doi: 10.1890/06-1439.1.

Hayes, R.D., Baer, A., Wotschikowsky, U., and Harestad, A.S. 2000. Kill rate by wolves on moose in the Yukon. Can. J. Zool. 78: 49-59. doi: 10.1139/z99-187.

Hegel, T. 2013. Yukon woodland caribou composition surveys, 2012. Yukon Fish and Wildlife Branch Technical Report PR-13-02. Whitehorse, Yukon, Canada.

Hervieux, D., Hebblewhite, M., Stepnisky, D., Bacon, M., and Boutin, S. 2014. Managing wolves (Canis lupus) to recover threatened woodland caribou (Rangifer tarandus caribou) in Alberta. Can. J. Zool. 92: 1029-1037. doi: 10.1139/cjz-2014-0142.

Hilderbrand, G.V., Farley, S.D., Robbins, C.T., Hanley, T.A., Titus, K., and Servheen, C. 1996. Use of stable isotopes to determine diets of living and extinct bears. Can. J. Zool. 74: 2080-2088. doi: 10.1139/z96-236.

Hobson, K.A., McLellan, B.N., and Woods, J.G. 2000. Using stable carbon $\left(\delta^{13} \mathrm{C}\right)$ and nitrogen $\left(\delta^{15} \mathrm{~N}\right)$ isotopes to infer trophic relationships among black and grizzly bears in the upper Columbia River basin, British Columbia. Can. J. Zool. 78(8): 1332-1339. doi: 10.1139/z00-069.

Huggard, D.J. 1993. Prey selectivity of wolves in Banff National Park. I. Prey species. Can. J. Zool. 71: 130-139. doi: 10.1139/z93-019. 
Jackson, A.L., Inger, R., Bearhop, S., and Parnell, A. 2009. Erroneous behaviour of MixSIR, a recently published Bayesian isotope mixing model: a discussion of Moore \& Semmens (2008). Ecology Letters 12: E1-E5. doi: 10.1111/j.1461-0248.2008.01233.x.

Jacoby, M.E., Hilderbrand, G.V., Servheen, C., Schwartz, C.C., Arthur, S.M., Hanley, T.A., Robbins, C.T., and Michener, R. 1999. Trophic relations of brown and black bears in several western North American ecosystems. J. Wildl. Manage. 63: 921-929. doi: $10.2307 / 3802806$.

James, A.R., Boutin, S., Hebert, D.M., Rippin, A.B., and White, J. 2004. Spatial separation of caribou from moose and its relation to predation by wolves. J. Wildl. Manage. 68: 799809. doi: $10.2193 / 0022-541$.

James, A.R., and Stuart-Smith, A.K. 2000. Distribution of caribou and wolves in relation to linear corridors. J. Wildl. Manage. 64: 154-159. doi: 10.2307/3802985.

Johnson, C.J., Ehlers, L.P., and Seip, D.R. 2015. Witnessing extinction-Cumulative impacts across landscapes and the future loss of an evolutionarily significant unit of woodland caribou in Canada. Biol. Conserv. 186: 176-186. doi: 10.1016/j.biocon.2015.03.012.

Karanth, K.U., and Sunquist, M.E. 1995. Prey selection by tiger, leopard and dhole in tropical forests. J. Anim. Ecol. 64: 439-450. doi: 10.2307/5647.

Kunkel, K.E., Pletscher, D.H., Boyd, D.K., Ream, R.R., and Fairchild, M.W. 2004. Factors correlated with foraging behavior of wolves in and near Glacier National Park, Montana. J. Wildl. Manage. 68: 167-178. Doi: 10.2193/0022-541.

Latham, A.D.M., Latham, M.C., Knopff, K.H., Hebblewhite, M., and Boutin, S. 2013. Wolves, white-tailed deer, and beaver: implications of seasonal prey switching for woodland caribou declines. Ecography, 36: 1276-1290. doi: 10.1111/j.1600-0587.2013.00035.x. 
586 587

Leblond, M., Dussault, C., Ouellet, J.P., and St-Laurent, M.H. 2016. Caribou avoiding wolves face increased predation by bears-Caught between Scylla and Charybdis. J. Appl. Ecol. 53: 1078-1087. doi: 10.1111/1365-2664.12658.

Losier, C.L., Couturier, S., St-Laurent, M.H., Drapeau, P., Dussault, C., Rudolph, T., Brodeur, V., Merkle, J.A., and Fortin, D. 2015. Adjustments in habitat selection to changing availability induce fitness costs for a threatened ungulate. J. Appl. Ecol. 52: 496-504. doi: $10.1111 / 1365-2664.12400$.

Marshall, R. 2015. Atlin Stratified Random Block Moose Surveys March 7-11, 2014. British Columbia Ministry of Forests, Lands and Natural Resource Operations, Smithers, British Columbia, Canada.

McLellan, B.N., and Hovey, F.W. 1995. The diet of grizzly bears in the Flathead River drainage of southeastern British Columbia. Can. J. Zool. 73: 704-712. doi: 10.1139/z95-082.

Mech, L.D., and Peterson, R.O. 2003. Wolf-prey relations. In Wolves: Behavior, Ecology and Conservation. Edited by L.D. Mech and L. Boitani. The University of Chicago Press, Chicago, Illinois, USA. pp. 131-160.

Merkle, J.A., Derbridge, J.J., and Krausman, P.R. 2011. Using stable isotope analysis to quantify anthropogenic foraging in black bears. Human-Wildlife Interactions 5: 159-167.

Merkle, J.A., Krausman, P.R., Stark, D.W., Oakleaf, J.K., and Ballard, W.B. 2009. Summer diet of the Mexican gray wolf (Canis lupus baileyi). Southwest. Nat. 54: 480-485. doi: 10.1894/CLG-26.1.

Metz, M.C., Smith, D.W., Vucetich, J.A., Stahler, D.R., and Peterson, R.O. 2012. Seasonal patterns of predation for gray wolves in the multi-prey system of Yellowstone National Park. J. Anim. Ecol. 81: 553-563. doi: 10.1111/j.1365-2656.2011.01945.x. 
609

610

611

612

613

614

615

616

617

618

619

620

621

622

623

624

625

626

627

628

629

630

631

Milakovic, B., and Parker, K.L. 2011. Using stable isotopes to define diets of wolves in northern British Columbia, Canada. J. Mammal. 92: 295-304. doi: 10.1644/10-MAMM-A-038.1.

Milakovic, B., and Parker, K.L. 2013. Quantifying carnivory by grizzly bears in a multi-ungulate system. J. Wildl. Manage. 77: 39-47. doi: 10.1002/jwmg.434.

Mowat, G., and Heard, D.C. 2006. Major components of grizzly bear diet across North America. Can. J. Zool. 84: 473-489. doi: 10.1139/z06-016.

Munro, R., Nielsen, S., Price, M., Stenhouse, G., and Boyce, M. 2006. Seasonal and diel patterns of grizzly bear diet and activity in west-central Alberta. J. Mammal. 87: 1112-1121. doi: 10.1644/05-MAMM-A-410R3.1.

Nielsen, S., Munro, R., Bainbridge, E., Stenhouse, G., and Boyce, M. 2004. Grizzly bears and forestry: II. Distribution of grizzly bear foods in clearcuts of west-central Alberta, Canada. For. Ecol. Manage. 199: 67-82. doi: 10.1016/j.foreco.2004.04.015.

Palomares, F., Ferreras, P., Fedriani, J.M., and Delibes, M. 1996. Spatial relationships between Iberian lynx and other carnivores in an area of south-western Spain. J. Appl. Ecol. 33: 513. doi: $10.2307 / 2405010$.

Peters, W., Hebblewhite, M., DeCesare, N., Cagnacci, F., and Musiani, M. 2013. Resource separation analysis with moose indicates threats to caribou in human altered landscapes. Ecography, 36: 487-498. doi: 10.1111/j.1600-0587.2012.07733.x.

Phillips, D.L. 2012. Converting isotope values to diet composition: the use of mixing models. J. Mammal. 93: 342-352. doi: 10.1644/11-MAMM-S-158.1.

Plummer, M. 2003. JAGS: A program for analysis of Bayesian graphical models using Gibbs sampling. In Proceedings of the 3rd International Workshop on Distributed Statistical Computing (DSC 2003), Vienna, Austria. pp. 20-22. 
632 Polfus, J., Hebblewhite, M., and Heinemeyer, K. 2011. Identifying indirect habitat loss and

633

634

635

636

637

638

639

640

641

642

643

644

645

646

647

648

649

650

651

652 avoidance of human infrastructure by northern mountain woodland caribou. Biol. Conserv. 144: 2637-2646. doi: 10.1016/j.biocon.2011.07.023.

Polfus, J.L., Heinemeyer, K., and Hebblewhite, M. 2014. Comparing traditional ecological knowledge and western science woodland caribou habitat models. J. Wildl. Manage. 78: 112-121. doi: 10.1002/jwmg.643.

Post, D.M. 2002. Using stable isotopes to estimate trophic position: models, methods, and assumptions. Ecology, 83: 703-718. doi: 10.1890/0012-9658.

Post, E. 2013. Ecology of climate change: the importance of biotic interactions. Princeton University Press, Princeton, USA.

Potvin, F., Jolicoeur, H., and Huot, J. 1988. Wolf diet and prey selectivity during two periods for deer in Quebec: decline versus expansion. Can. J. Zool. 66: 1274-1279. doi: 10.1139/z88-186.

R Core Team. 2014. R: A language and environment for statistical computing. R Foundation for Statistical Computing, Vienna, Austria.

Raine, R.M., and Kansas, J.L. 1990. Black Bear Seasonal Food Habits and Distribution by Elevation in Banff National Park, Alberta. Int. Conf. Bear Res. Manage. 8: 297-304.

Schlaepfer, M.A., Runge, M.C., and Sherman, P.W. 2002. Ecological and evolutionary traps. Trends Ecol. Evol. 17: 474-480. doi: 10.1016/S0169-5347(02)02580-6.

Schoener, T.W. 1974. Resource partitioning in ecological communities. Science, 185: 27-39. doi: 10.1126/science.185.4145.27. 
653 Seip, D.R. 1992. Factors limiting woodland caribou populations and their interrelationships with

654

655

656

657

658

659

660

661

662

663

664

665

666

667

668

669

670

671

672

673 wolves and moose in southeastern British Columbia. Can. J. Zool. 70: 1494-1503. doi: 10.1139/z92-206.

Smith, D.W., Peterson, R.O., and Houston, D.B. 2003. Yellowstone after Wolves. BioScience, 53: 330-340. doi: 10.1641/0006-3568.

Stotyn, S.A. 2008. Ecological interactions of mountain caribou, wolves and moose in the North Columbia Mountains, British Columbia. University of Alberta.

Stotyn, S.A., McLellan, B.N., and Serrouya, R. 2007. Mortality sources and spatial partitioning among mountain caribou, moose, and wolves in the north Columbia Mountains, British Columbia. Columbia Basin Fish and Wildlife Compensation Program, Nelson, British Columbia, Canada.

Stuart-Smith, A.K., Bradshaw, C.J., Boutin, S., Hebert, D.M., and Rippin, A.B. 1997. Woodland caribou relative to landscape patterns in northeastern Alberta. J. Wildl. Manage. 61: 622633. doi: $10.2307 / 3802170$.

Taku River Tlingit First Nation, and Province of British Columbia. 2010. Interim collaborative harvest management plants for Atlin caribou, Atlin east sheep and moose and lower Taku grizzly bear. Taku River Tlingit First Nation and Province of British Columbia, British Columbia, Canada.

Taku River Tlingit First Nation, and Province of British Columbia. 2011. Wóoshtin wudidaa Atlin Taku Land Use Plan. British Columbia Ministry of Forests, Lands and Natural Resource Operations, Atlin, British Columbia, Canada. 
674 Urton, E.J., and Hobson, K.A. 2005. Intrapopulation variation in gray wolf isotope $\left(\delta^{15} \mathrm{~N}\right.$ and $\left.675 \quad \delta^{13} \mathrm{C}\right)$ profiles: implications for the ecology of individuals. Oecologia, 145: 316-325. doi:

676

677 678

679 680 681 682 683 684 685 686 687 688 689 690 691 692 693 694 695 696 10.1007/s00442-005-0124-2.

Vors, L.S., and Boyce, M.S. 2009. Global declines of caribou and reindeer. Glob. Chang. Biol. 15: 2626-2633. doi: 10.1111/j.1365-2486.2009.01974.x.

Walker, A.B., Parker, K.L., Gillingham, M.P., Gustine, D.D., and Lay, R.J. 2007. Habitat selection by female Stone's sheep in relation to vegetation, topography, and risk of predation. Ecoscience, 14: 55-70. doi: 10.2980/1195-6860.

Whittington, J., Hebblewhite, M., DeCesare, N.J., Neufeld, L., Bradley, M., Wilmshurst, J., and Musiani, M. 2011. Caribou encounters with wolves increase near roads and trails: a timeto-event approach. J. Appl. Ecol. 48: 1535-1542. doi: 10.1111/j.13652664.2011.02043.x.

Wittmer, H.U., McLellan, B.N., Serrouya, R., and Apps, C.D. 2007. Changes in landscape composition influence the decline of a threatened woodland caribou population. J. Anim. Ecol. 76: 568-579. doi: 10.1111/j.1365-2656.2007.01220.x.

Wittmer, H.U., Sinclair, A.R., and McLellan, B.N. 2005. The role of predation in the decline and extirpation of woodland caribou. Oecologia, 144: 257-267. doi: 10.1007/s00442-005$0055-\mathrm{y}$

Young Jr, D.D., and McCabe, T.R. 1997. Grizzly bear predation rates on caribou calves in northeastern Alaska. J. Wildl. Manage. 61: 1056-1066. doi: 10.2307/3802102.

Zager, P., and Beecham, J. 2006. The role of American black bears and brown bears as predators on ungulates in North America. Ursus, 17: 95-108. doi: 10.2192/1537-6176. 
697 Figures

698 Figure 1. General location of the study area along with sampling locations within the traditional

699 territory of the Taku River Tlingit First Nation (TRTFN) territory in northwestern British

700 Columbia, Canada.

701

702 Figure 2. Mean (with SD bars in black) prey carbon $\left(\delta^{13} \mathrm{C}\right)$ and nitrogen $\left(\delta^{15} \mathrm{~N}\right)$ isotope values 703 from tissue samples (guard hair for mammals and above ground tissue for plants) collected in the 704 traditional territory of the Taku River Tlingit First Nation in northwestern British Columbia, 705 Canada, 2009-2010. See Supplementary Table S1 for statistical tests of differences among the 706 mammalian prey items.

707

708 Figure 3. Mean (with SD bars in black) predator carbon $\left(\delta^{13} \mathrm{C}\right)$ and nitrogen $\left(\delta^{15} \mathrm{~N}\right)$ isotope values 709 based on samples of grey wolf (Canis lupus; a), black bear (Ursus americanus; b), and grizzly 710 bear (U. arctos; c) guard hairs representing early (tip section), mid (middle section), and late 711 (root section) summer growth. Hair samples were collected in the traditional territory of the Taku 712 River Tlingit First Nation in northwestern British Columbia, Canada, 2009-2010.

714 Figure 4. Mean posterior distributions (with SD bars in black) of the proportional contribution of 715 caribou (Rangifer tarandus), beaver (Castor canadensis), moose (Alces alces), and vegetation in 716 the diets of grey wolves (Canis lupus), black bears (Usus americanus), and grizzly bears ( $U$. 717 arctos) in early, middle, and late summer of 2009-2010 in the traditional territory of the Taku 718 River Tlingit First Nation in northwestern British Columbia, Canada. Distributions calculated 
719 from a Bayesian n-mixture model of carbon $\left(\delta^{13} \mathrm{C}\right)$ and nitrogen $\left(\delta^{15} \mathrm{~N}\right)$ isotope values derived 720 from guard hairs (mammals) and above ground whole tissue (vegetation). 


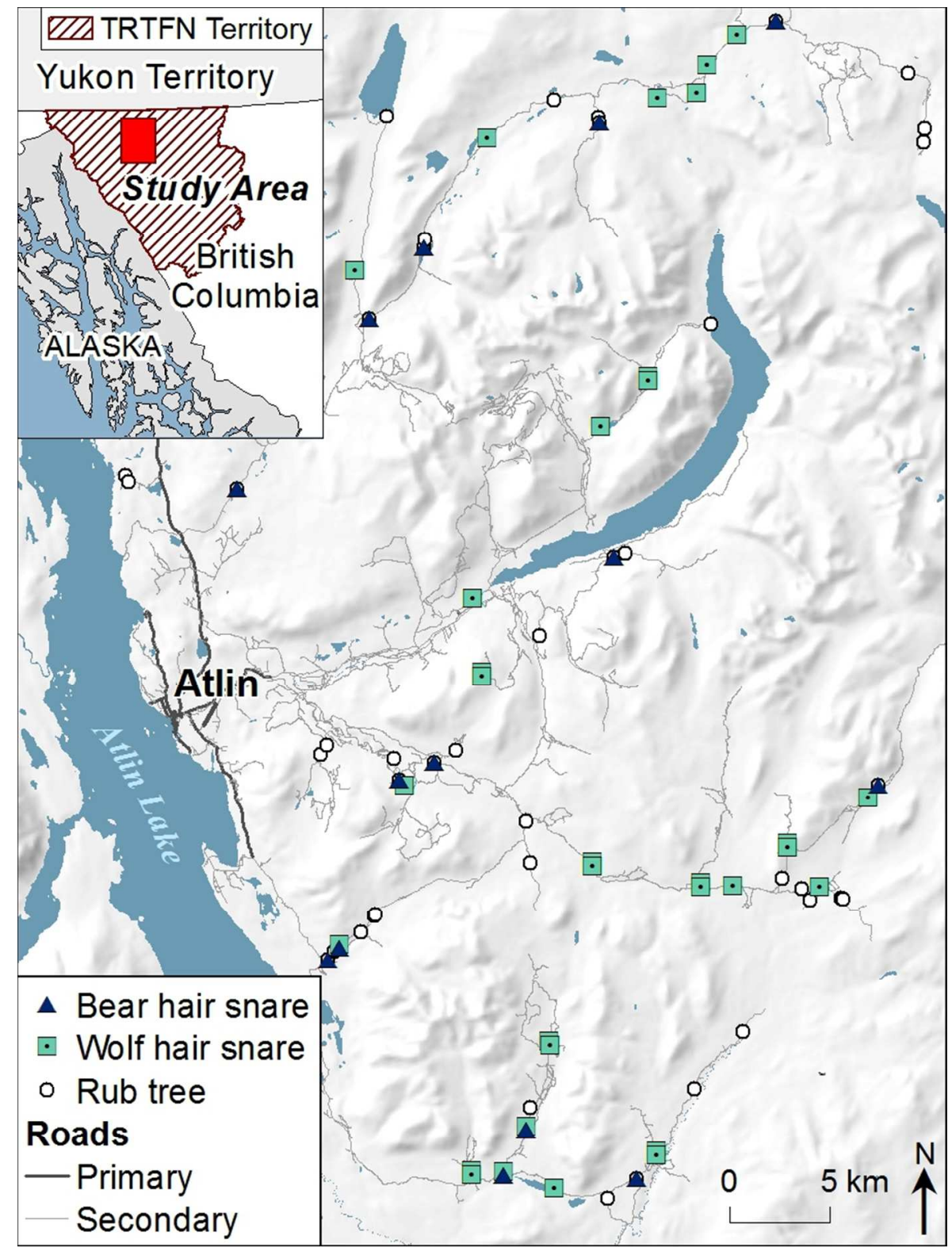

$76 \times 101 \mathrm{~mm}(300 \times 300 \mathrm{DPI})$ 


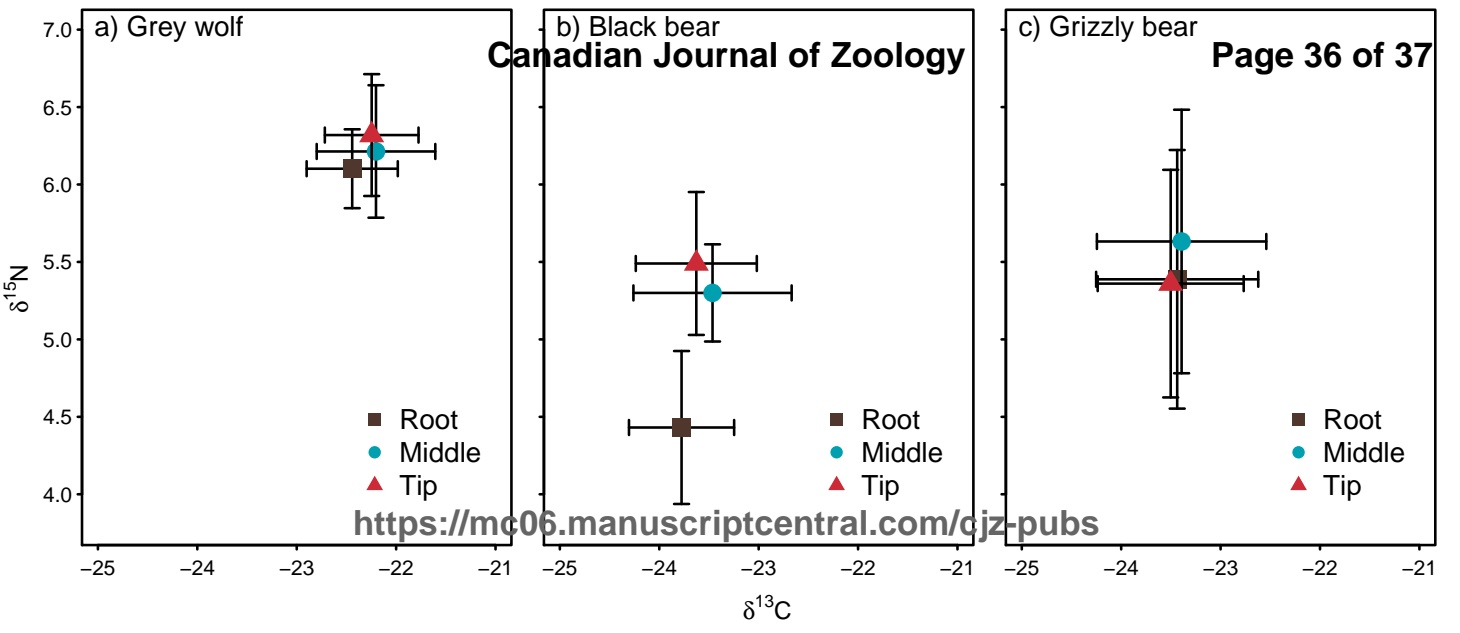




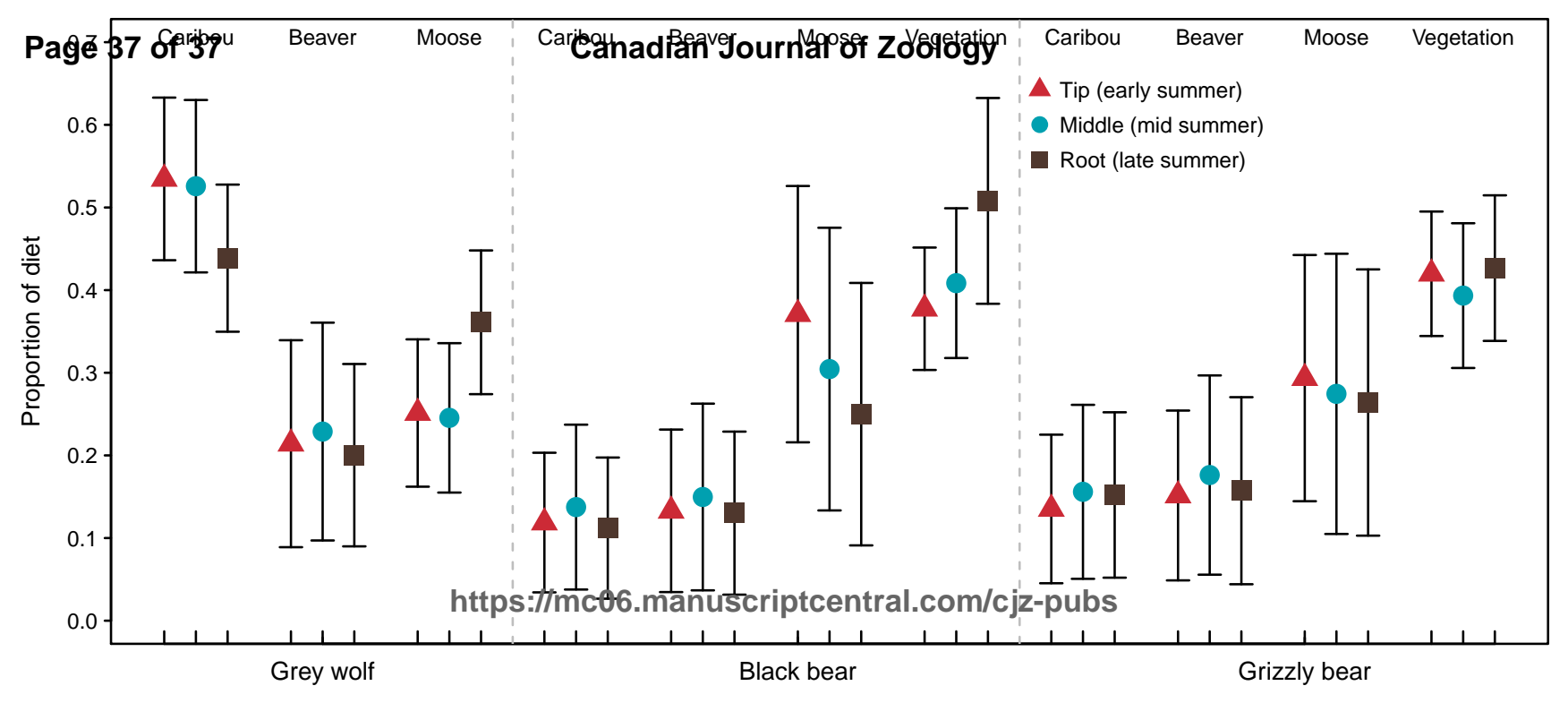

